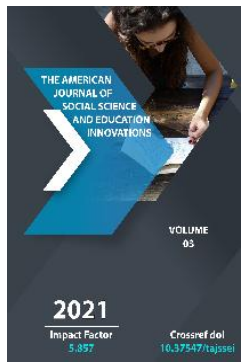

\title{
Innovative-Variative Approach To The Process Of Training Of Public Education Workers As A Developing Model Of Professional Development
}

\author{
Mahmudov Sarvar Yuldashevich \\ Candidate Of Pedagogical Sciences, Uzbekistan
}

\section{ABSTRACT}

Innovative and variable technologies to ensure the quality and competitiveness of the education system through continuous training of teachers in the world have been introduced into the educational process. "Sustainable Development Goals (SDGs)" adopted at the 70th anniversary session of the UN General Assembly, "United Nations Educational, Scientific and Cultural Organization", "European Higher Education Area (EHEA)" , The European Center for the Development of Vocational Education (CEDEFOP), the Center for Lifelong Learning (DIE) and the Institute for International Cooperation of the German Association of People's Universities (DVV International) "in the concepts of " competency-based education Systematic work is being carried out on the implementation of large-scale practical projects to improve the mechanisms of humanization and development of education through the implementation of the model "learning).

\section{KEYWORDS}

Public education, training, development, model, quality, variability, innovation. 
Improving the mechanisms of development of general professional and social knowledge of teachers in the world educational and research institutions, the introduction of the latest scientific advances, innovations, IT technologies in the process of professional development, modern e-learning resources, multimedia, distance learning, adult education On the basis of the program "Curriculum globALE", which sets the basic standards for the qualifications of teachers working in the field, scientific research is conducted to ensure the professionalization of andragogic education at the international level. At the same time, special attention is paid to research on improving the process of professional development of teachers on the basis of modernization of information and didactic support of innovative and variable approaches, providing content based on need.

Bringing the system of advanced training of public educators in our country to a qualitatively new level, the introduction of new, improved alternative mechanisms of professional development, the introduction of distance learning courses based on online and offline technologies in the digital economy, legal and regulatory framework for updating educational resources based on international experience created and developed the material and technical base. The Action Strategy for the further development of the
Republic of Uzbekistan identifies "improving the system of continuing education, training highly qualified personnel in accordance with the modern needs of the labor market, creating effective mechanisms for the implementation of scientific and innovative achievements." As a result, the introduction of variability, hierarchical, hierarchical systems and distance forms in the process of professional development of public educators will expand the opportunities for further improvement of the system of advanced training on the basis of innovative-variable approaches.

Theoretical foundations of the innovative approach to the training process and the development of the training system depend primarily on the development of innovations that lead to qualitative changes in the educational process, meeting the requirements of the state, society and educational institutions, the methodological principles of continuing education and training of public educators. Innovative-alternative approach in the system of professional development, ie the provision of educational services in the system of professional development, taking into account the needs of educational institutions and teachers.

The theoretical foundations of the innovativevariable approach to the system of advanced training are as follows. 


\begin{tabular}{|c|c|c|}
\hline Basic & Idea & Results \\
\hline $\begin{array}{l}\text { Meeting the requirements } \\
\text { of the state, society and } \\
\text { educational institutions to } \\
\text { the system of professional } \\
\text { development of public } \\
\text { educators, ensuring } \\
\text { continuity of professional } \\
\text { development, relevance to } \\
\text { professional activities, } \\
\text { based on the needs of } \\
\text { teachers }\end{array}$ & $\begin{array}{l}\text { Introduction of mechanisms for } \\
\text { continuous updating of professional } \\
\text { knowledge, skills and abilities of } \\
\text { public educators, increase of } \\
\text { professional training necessary to } \\
\text { ensure the quality of professional } \\
\text { development in accordance with } \\
\text { modern requirements, introduction } \\
\text { of direct and indirect forms of } \\
\text { professional development based on } \\
\text { the principles of variability and } \\
\text { complementarity }\end{array}$ & $\begin{array}{l}\text { Implement a system of continuous } \\
\text { professional development that } \\
\text { allows for regular professional } \\
\text { self-development, improve the } \\
\text { content of alternative curricula } \\
\text { and programs, introduce } \\
\text { innovative forms and methods of } \\
\text { professional development of } \\
\text { teachers using modern } \\
\text { information and communication } \\
\text { technologies }\end{array}$ \\
\hline
\end{tabular}

Regularity - the conceptual principles of regular training determine the goals, content of education, organizational structures and the continuity of pedagogical technologies. As a generalization of the theoretical and practical rules of continuous, regular professional development, andragogy reveals the theoretical and practical problems of adult education in the process of continuing education.

The introduction of an innovative-variable approach to the system of advanced training implies the creation of an effective system of quality management of advanced training. The quality of education, like other socioeconomic systems, will have to be far from spontaneous management and have clear systemic management. The introduction of an innovative-variable approach to the system of professional development can not be done only in an administrative way. In this process, as noted above, all institutions of society, all subjects of the educational process will have to participate.
Also, to ensure the quality of the system of innovative-variable approach to the system of advanced training, the following sociopedagogical conditions will be needed: Quality control tools, goals and conditions of using the results of advanced training in terms of increasing the responsibility and independence of training institutions and liberalization and democratization should be

As a generalization of the theoretical and practical rules of continuing education, andragogy reveals the theoretical and practical problems of adult learning in the process of continuing education.

Targeted use of the principles of the andragogic approach in the selection of educational technologies in the process of professional development allows to create a methodological basis for the paradigm of individual-activity adult education.

The purpose of education in the andragogic model is to rethink the formed system of knowledge, skills, abilities, experiences. In this case, the effect of professional development as a result of interaction with an experience 
that is new to the learner - is manifested in the form of new personal instructions, positions, thinking strategies, relationships, new qualities of life, etc.

\begin{tabular}{|c|c|}
\hline $\begin{array}{l}\text { Innovative } \\
\text { approach - the } \\
\text { principles of } \\
\text { variable-level } \\
\text { training }\end{array}$ & $\begin{array}{l}\text { 1. Adult education is conditioned by a person's growing need for lifelong learning. } \\
\text { 2. Adult education is based on subjectivity as a characteristic of a person who acts } \\
\text { with understanding in the process of self-determination. } \\
\text { 3. Adult education is aimed at providing the individual with the modern content } \\
\text { of education and the conditions for mastering the appropriate ways of mastering } \\
\text { it. }\end{array}$ \\
\hline $\begin{array}{l}\text { Innovative } \\
\text { approach - the } \\
\text { principles of } \\
\text { teaching in varia- } \\
\text { tiv-step training }\end{array}$ & 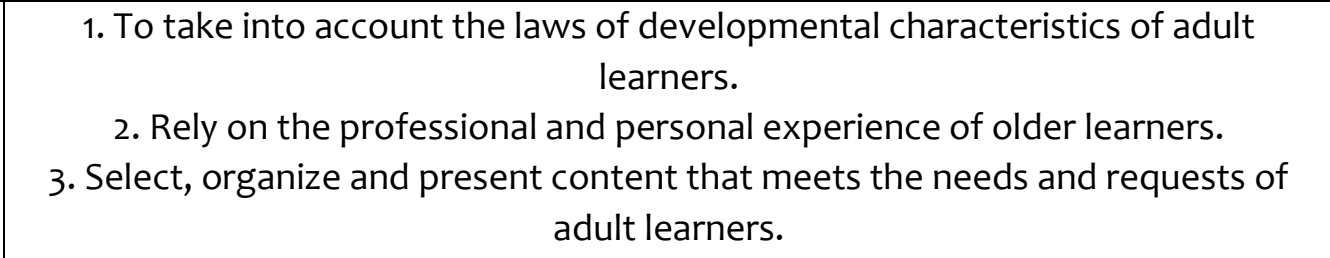 \\
\hline $\begin{array}{l}\text { Innovative } \\
\text { approach - the } \\
\text { principles of } \\
\text { teaching in } \\
\text { differentiated-level } \\
\text { training }\end{array}$ & $\begin{array}{l}\text { 1. Rely on the opportunities available to adult learners for their development. } \\
\text { 2. Willingness of older learners to communicate in the process of sharing their } \\
\text { professional and personal experiences. } \\
\text { 3. Critical acceptance of knowledge by older learners as an open system and its } \\
\text { creative use to overcome their own personal difficulties. }\end{array}$ \\
\hline
\end{tabular}

Introduction of an innovative-variable approach to the system of professional development Introduce mechanisms for continuous updating of professional knowledge, skills and abilities of public educators, increase the level of professional training necessary to ensure the quality of professional development in accordance with modern requirements, direct and indirect forms of professional development and serve as an important resource for the implementation and improvement of the system of professional development of public educators, based on the principles of complementarity.

The application of the andragogic model of education in the system of in-service training of public education allows to overcome the contradiction between innovation-oriented practice and insufficiently scientifically substantiated competencies of pedagogical staff.

The current reforms in the country require the search for new pedagogical opportunities to develop the spiritual and cultural qualities and professional competence of members of society, especially public educators, to increase the necessary professional training of teachers, to develop professional qualities, to radically change the way of life in the information society. It is impossible to form and train worthy personnel for the system of public education without paying attention to the inclusion of the realities of scientific, technical and social development in the content of professional development.

In addition, an innovative-variable approach to the system of in-service training, which allows to expand the understanding of educational technologies as methods of 
organizing training activities in the selection of different stages of the training process, continuity as a methodological principle of research and an important global problem at the current stage of socioeconomic development. .

Exploring the possibilities of applying the concept of "variable skills development in the process of professional development" requires defining the meaning of the concept of "variability". Several approaches formed in scientific practice have been analyzed in interpreting this concept.

Innovative-variable approach in the system of advanced training means not only the use of variable programs (in-depth, extended level) that differ in content, but also programs that differ in teaching methods, forms and educational technologies.

Consequently, variability will be focused on the requirements, needs, capabilities of the trainee.

Also, the variable approach to professional development is based on the following factors:

- Variety of professional development programs depending on the level of professional competence, pedagogical potential of public educators;

- Taking into account the growing demand and development of the system of advanced training;

- Taking into account the development of modern information and communication and pedagogical technologies in the system of professional development and the growing demand for them.

In implementing a varied approach to professional development, professional development institutions, education management bodies should focus on the following areas:

- Aimed at increasing the level of professional competence and pedagogical capacity of employees of public educational institutions (organization of short-term, targeted training courses and the development of training programs that take into account all the requirements and needs);

- It is necessary to develop a new, modern professional profile of public educators (socio-pedagogical model of public educator) based on the requirements of state, public and educational institutions;

- Take measures to provide moral and material incentives for public educators based on their training on the basis of a varied approach.

Taking into account the above considerations, radical improvement of the system of inservice training will take into account the needs of public educators and will lead to the accelerated use of alternative training programs, pedagogical technologies. This approach ensures the integration of the system of professional development into the world education system, the application of advanced pedagogical ideas and technologies in the process of professional development. 
As a result of the study, the adaptive, complementary and innovative functions of professional development were identified:

- The essence of the adaptation function is to prepare public educators for modern educational situations, to direct their knowledge, skills and abilities to adapt to today's sociopedagogical requirements;

- $\quad$ The essence of the filling function is to fill the gaps that arise during the practical pedagogical activity or in the process of professional development;

- $\quad$ The essence of the innovative function reflects the need to adapt the psychological and pedagogical training of public educators to the results of scientific and technological development, inspires teachers to creative research in their profession.

In general, the training of public educators is relevant for most countries. In the process of professional development, the requirements and needs of the educator are embodied on the one hand, and the requirements of the development of society on the other.

In developed countries, the state provides pedagogical staff with the opportunity to update their knowledge and skills, which is in the interests of the teacher, his students, the educational institution, the state and society. At the same time, the responsibility for the professional development of the educator is shared among them.

Innovative-variable approach to professional development of public educators is recognized by the pedagogical community as a developing model of continuing education, and a model of meeting the needs of teachers through in-service training through innovativevariable approach to professional development, as well as information in the creation of electronic didactic tools. it is important to use telecommunication technologies.

Variable forms of professional development of pedagogical staff allow to methodically combine independent education of the teacher without separation from professional activity. This means, first of all, that not only the educator will not leave his workplace, but also the distance between the theory and practice of education will be reduced.

As a result of the formation of a system of relationships, full-fledged relationships are formed, which allow to develop, test and offer innovative methods of activity to the professional community.

Underlying the principle of mutual exchange of experience by public educators is that any knowledge is open to every participant in the pedagogical community. At the same time, it allows for a variety of forms, methods and means of professional interaction within the pedagogical community.

Further improvement of the system of advanced training, which is an important part of the system of continuing education, expansion of state and non-state network of advanced training institutions, strengthening their material and technical base, providing them with highly qualified teachers, sharply increasing the requirements of public educators, modern education programs and technologies. 
The process of variable training is important in the implementation of educational goals of all participants of the training process, the establishment of joint activities in the selection of educational content, educational technologies, activities and means and methods of communication on the basis of state requirements.

The innovative-variable model of the training system can not be implemented only in an administrative way, in this process, as noted above, it is necessary to involve all institutions of society, all subjects of the training process.

Skills development always begins with the activation of the listener's past experience in a new situation. This can be due to mastery and need-basedness, both in gaining experience and in subsequent training.

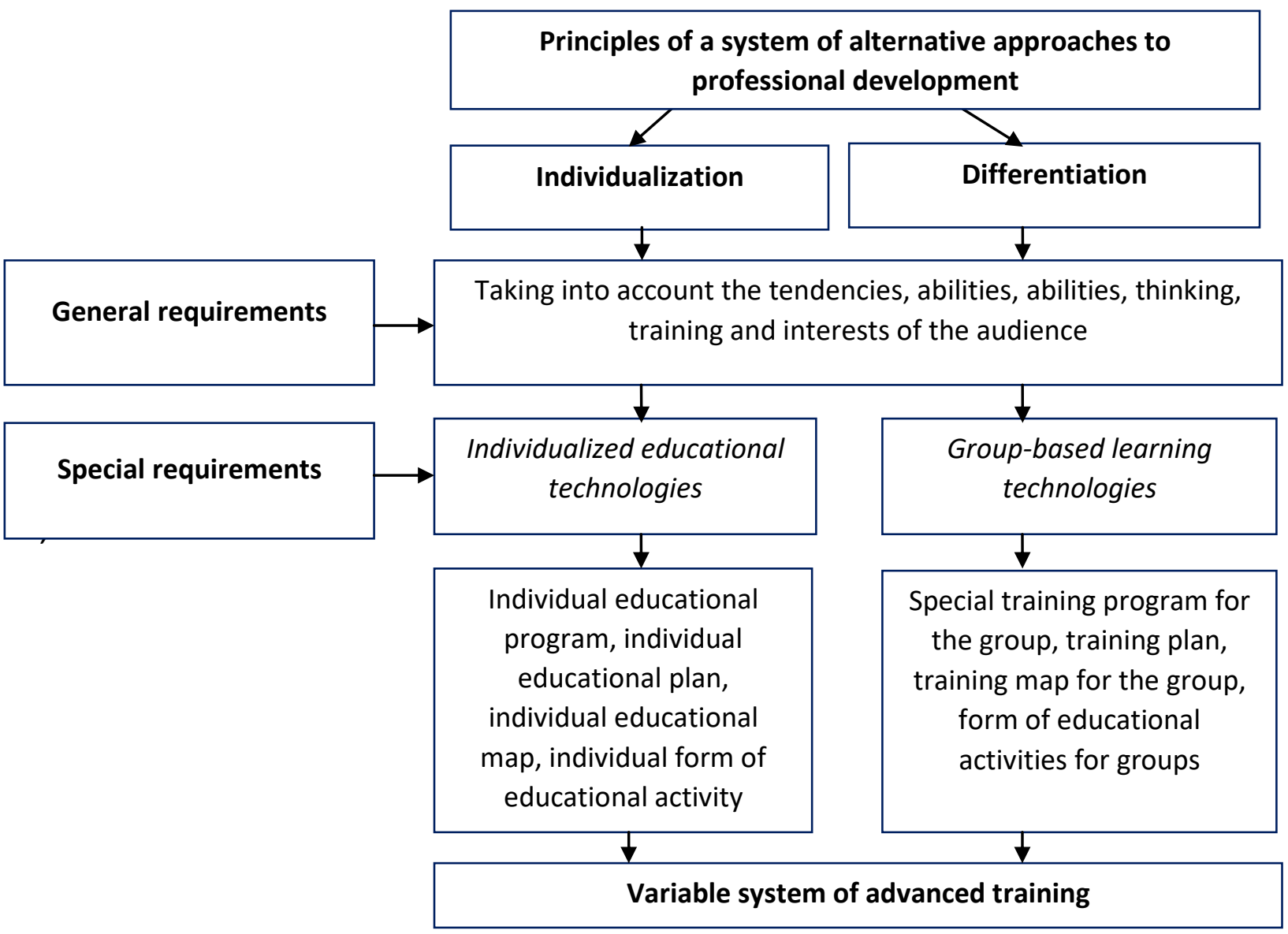


An innovative approach to professional development is a complex activity related to the creation, assimilation, use, dissemination and development of innovation. Implementation of innovative processes in professional development is one of the important conditions for improving the quality of professional development.

Innovation in professional development (innovation, innovation) - sustainable innovation in the activities of the training institution its development and operation, including elements goal-oriented, which effectively affects the performance change

Innovative - variable technologies in the process of professional development for students (listeners) specific subject (topic)

It is a set of modern educational-methodical, information-didactic forms of advanced training and information-communication technologies, based on the needs of the audience, aimed at imparting knowledge and formation of personality.

Innovative information-didactic forms of professional development - taking into account the abilities and interests of the learner

Education is a system of interaction between teacher and student based on psychological, general pedagogical, didactic and personal methodological procedures aimed at designing the content of education in accordance with the purpose of education, the needs of the audience and the implementation of pedagogical, information and communication methods, forms and teaching methods.
Forms of improving the system of professional development of public educators on the basis of an innovative approach - a design that provides a high level of efficiency, consisting of pedagogical laws, goals, principles, content, form, methods, teaching aids and information and communication technologies and methods of education. system.

Regular professional development of public educators is one of the leading means of implementing a person-centered paradigm of pedagogical education, which reflects the system of conditions to ensure the continuity and continuity of professional and personal development of teachers. It is the regularity, membership of all stages of professional and pedagogical training and advanced training; unity of formal and informal professionalpedagogical independent education; unity of general (general cultural, generaldevelopmental) and professional-pedagogical education; includes regular, continuous updating of all elements of the pedagogical education system in accordance with the changing living conditions.

The third chapter of the dissertation also deals with the development of the informationeducational environment of the system of professional development of public educators, the objective result of the development of the process of informatization of education, the essence of professional communication not only local trainees but also trainees from other regions and countries. The informationeducational environment is a tool for the transmission and rapid exchange of educational information, on the basis of which the ability of trainees to jointly and collectively solve pedagogical problems has been studied. 
The information-educational environment of professional development is organized on the basis of telecommunication technologies, has a common problem, purpose, methods and methods of activity, is aimed at achieving joint results, professional, educational, research, creative and scientific activities of partners.

Any problem solution requires integrated knowledge. The information-educational environment requires in-depth integration of knowledge, knowledge not only of the field of knowledge on the problem under study, but also of the characteristics of the national culture of the partner, his worldview. This means the formation of a culture of dialogue.

The synthesis of andragogical and personalactivity approaches combined with the conceptual ideas of distance learning in the process of professional development provides a new quality of continuous pedagogical education. The peculiarity of the work on the theoretical understanding of the idea of distance education is that most of the work on the theory of distance education is a synthesis of pedagogical, organizational, economic and other approaches. The last thirty years have been a global phenomenon of educational and information culture, changing the face of distance education systems. A whole industry of educational services, united under the common name of "distance education", has emerged and is developing rapidly, covering a very large number of learners.

Thus, the difference between distance learning and other types, first of all, full-time training, is a method of learning through indirect interactive communication, where certain means and technologies of communication do not occupy an important feature of distance learning.

The need for independent education of public education staff, on the one hand, through the characteristics of pedagogical activity, its social role, on the other hand, through the ever-changing conditions of pedagogical work, the needs of society, the evolution of science and practice, increasing educational demands; based on.

The following characteristics have been identified as a type of independent learning activity.

- Systematic learning activities of the teacher;

- Activities aimed at obtaining knowledge, skills and any systematized information by the teacher.

- In the process of independent learning, the teacher to some extent makes his own choice.

Independent education has a specific content, internal organization and procedural dynamics associated with the stage of professional and personal development of the teacher, which are reflected in the direction, goals, means, methods and objectives of independent education.

The teacher's independent professional education is an integral part of the following structure:

Continuing pedagogical education $\rightarrow$ variant training $\rightarrow$ independent education 
Independent education serves as a support

for the professional activity of the teacher.

Independent education as a separate form of activity has its own structure: motives, goals, means, techniques, technologies of professional and pedagogical activity.

The model of independent education includes an integrated information and communication environment, which variably determines the role of various - technological, pedagogical, organizational and methodological factors.

Based on the above theoretical considerations, we have defined the sociopedagogical model of research work, the organization of the system of professional development of public educators on the basis of an innovative-variable-step approach.

Many educators are not sufficiently prepared for independent educational activities, both personally and organizationally, they find it difficult to explain the essence of innovative variable-level forms of professional development. 


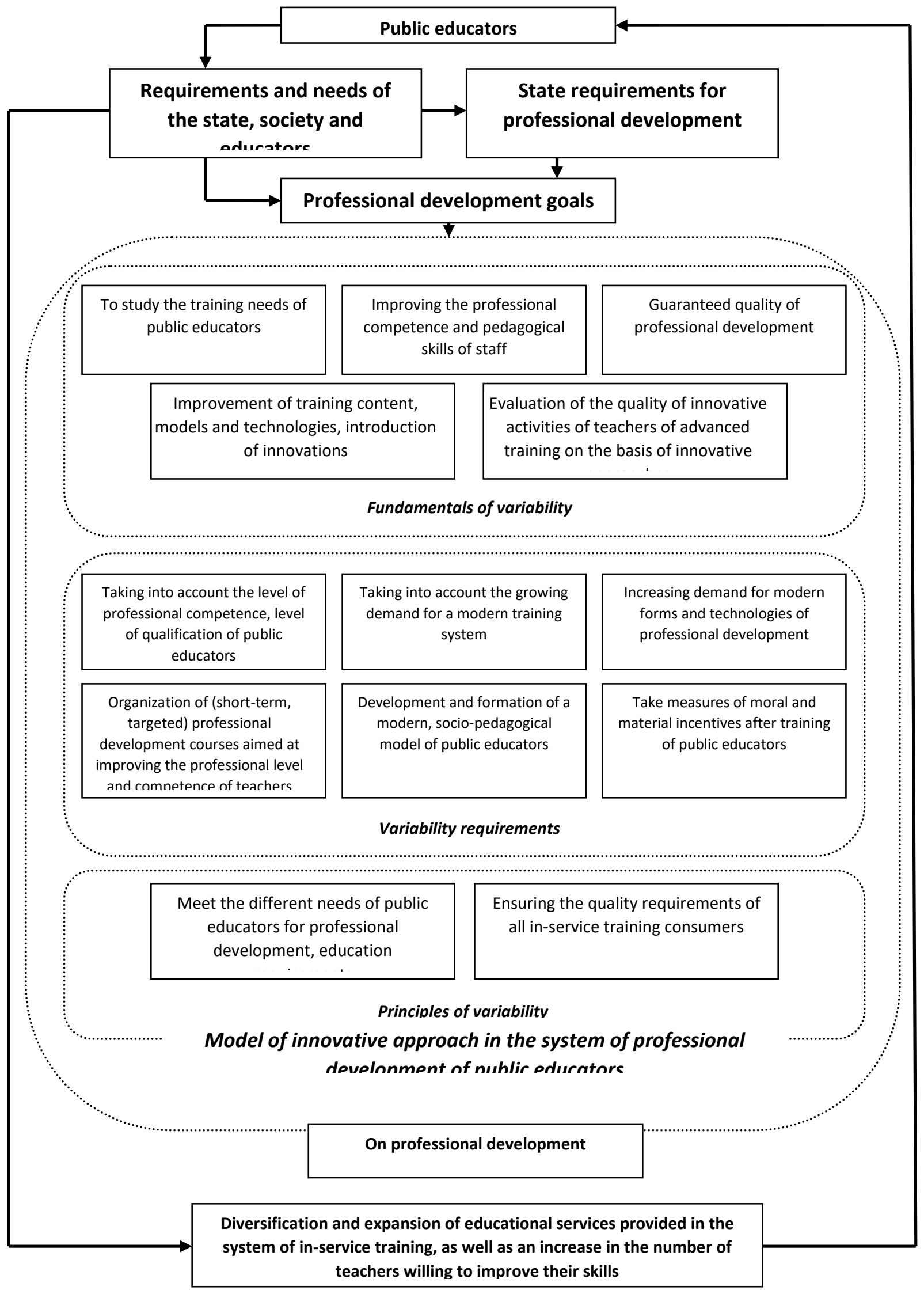


Socio-pedagogical model of organizing the system of professional development of public educators on the basis of innovative-variable approach

Based on the requirements of improving the system of professional development of public educators on the basis of innovative-variable approach, based on the results of the study, we came to the following conclusions:

1. The level of professional competence of public educators was recognized as a criterion for the development of society and the maturity of students, and serious attention was paid to the study of its essence from a socio-philosophical, ethical and pedagogical point of view. Today, when the processes of globalization and information exchange are accelerating, the system of professional development is based on the provision and development of various levels of professional development based on the needs of students, the gradual improvement of the system of advanced training.

2. The analysis showed that the innovativevariable approach to professional development includes the areas of informatization, fundamentalization, continuity of education. Applying it to the in-service training process will lead to a review of the content and technology of in-service training, identifying the training needs of the trainees and organizing the training on this basis.

3. The most important indicators of the theory and practice of professional development are: interdisciplinary, comparative nature of research, integration of scientific and pedagogical knowledge, integration of teaching with research activities, teachers' use of new information technologies in research activities.
4. The rule that the main method of the innovation approach is the analysis of the experience of students (listeners) was approved. This method allows students to acquire new knowledge or new educational content as a new learning experience, using effective methods and techniques of professional development activities, effectively involving their personal experiences.

5. The implementation of the andragogic model of education in the system of professional development has been proven to eliminate the contradiction between innovation-oriented practice and insufficient scientific support of modern educational practice of pedagogical staff.

6. The essence of the innovative approach to professional development in terms of conditions or opportunities that contribute to the personal development of teachers and the clear disclosure of the educational potential of the educational environment.

7. It was confirmed that the development of alternative training programs is an objective result of the development of the need-based training process.

8. Socio-pedagogical model of the system of advanced training of public educators on the basis of innovative-variable approach has been developed.

9. The solution of modern educational problems is based on the principle that the optimal model for meeting the educational needs of teachers - as an organizational and didactic form of education, is a variable-level model of professional development, which differs 
from other forms of educational communication. At the same time, information and communication technologies used in distance learning are its means, and their role varies depending on the model of organization of the educational process.

10. Innovative-variable skills development can be considered as a basic concept for both continuing pedagogical education and distance learning. Innovative-variable skills development in relation to the concept of continuing pedagogical education plays the role of an educational mechanism for the implementation of the concept. Innovative-variable-level professional development plays the role of a didactic principle in relation to distance learning as an organizational form of continuing pedagogical education. Variety-level training on the basis of combining educational and professional activity of the teacher in educational institution, synthesis of independent educational and methodical work, provides openness, variability, variability of forms and types taking into account both needs of teachers and objective needs of public education system.

11. It is noted that the main technological component of the information and communication environment in the model of distance education is innovative and varied training, and the individual program of professional development is a structured action program of teacher training in the information and communication environment.

12. Didactic tools of variable skills development, which are a means of reflecting, controlling and managing the content of the student's learning activities, were analyzed. Innovative - the main didactic tool for differentiated training is a varied curriculum and training complexes. Summarizing the results of experimental work conducted in the framework of the study, the following conclusions can be drawn:

13. Direct forms of professional development of pedagogical staff are not interesting enough for teachers because they do not include changing organizational forms of pedagogical education (both direct and indirect).

14. Methodical work of teachers in the main workplace (educational institutions) does not meet the needs of their professional and personal development. Most educators place great emphasis on different forms of independent learning, but very few educators participate in practice in indirect forms of professional development.

15. Most educators are not sufficiently prepared for both innovative and varied skills development, both personally and organizationally; they find it difficult to explain the essence of innovative-variable skills development. Educators lack the skills and abilities to make the most of their free time and to identify their needs for professional development.

16. The results obtained from the implementation of the formative experimental program allowed to conclude that there are favorable conditions for the introduction of new content and organizational forms in the system of professional development of teachers.

17. The analysis of the level of readiness of teachers for personal and professional development showed that they have changed values and motivation to improve innovative-variable-level skills, increase teachers' self-esteem; 
associated with having self-reflection techniques.

18. The results of empirical research, on the one hand, allowed to distinguish the most important features of innovativevariable training of teachers, on the other hand, to confirm the hypothesis about the different ratios of forms and content of innovative-variable training at the stages of professional development of teachers.

19. The results of experimental training allow us to emphasize the accuracy of the assumptions made on the basis of a theoretical analysis of the problem we are interested in.

20. The results of the study, without claiming to fully disclose the problem, the next directions of its development: the search for alternative pedagogical technologies that will allow teachers to activate innovative-variable training activities, distance learning to ensure innovativevariable-level training in the system of professional development expanding the use of technology.

21. The results of experimental training allow us to emphasize the accuracy of the assumptions made in the theoretical analysis of the problem we are interested in.

22. Based on the results and findings of the study, appropriate recommendations were developed for training institutions to improve innovative - variable-level training.

The dissertation does not cover all issues related to the improvement of the system of professional development of public educators on the basis of innovative-variable approach, and it is objective to identify innovative forms and technologies of professional development of teachers and conduct various theoretical and practical research. explains the possibilities.

\section{REFERENCES}

1. Makhmudov S.Yu. Variable system of continuous professional development as a means of improving the management of professional growth of teachers of secondary specialized, vocational education // Professional Education. - Moscow, 2005. -№3. - S. 3440.

2. Maxmudov S.Yu. The role of professional development in the training of competitive professionals // Educational technologies. - Tashkent, 200. -№7. - B. 10-17.

3. Maxmudov S.Yu. Problems of improving the system of professional development // Vocational education. - Tashkent, 2006. -№6. - B. 22-29.

4. Maxmudov S.Yu. Conceptual bases of development of modular curricula and programs for advanced training and retraining courses // Scientificmethodical bases of quality assurance of training, retraining and advanced training of pedagogical staff for secondary special, professional education: Republican scientificpractical conference. - Tashkent. 2006. Б. 89-96.

5. Maxmudov S.Yu. Technology povыsheniya kvalifikatsii pedagogov // Lifelong learning: Continuing education in the interests of sustainable development: 13th International Conference. - Russia. St. Petersburg. 2015. - Б. 211-218. 
6. Makhmudov SY Improving the system of professional development of public educators on the basis of innovativevariable approach // Continuing education. - Tashkent, 2020. -№3. - B. 68-72. . (13.00.00 №9,2020).

7. Makhmudov S.Yu. Innovation is a variation of yondashuv asosida malaka oshirish, ta'lim sifatini ta'minlash omilidir // Khalq ta'limi. - Tashkent. 2020. -№4. - B. 31-38. (13.00.00 No. 17, 2020).

8. Makhmudov. S., Innovative - variant approach to improving the qualification of pedagogical personnel as a main factor in providing the quality of education - European Journal of Research and Reflection in Educational Sciences Vol. 8 No. 12, 2020 Part III. P.199-205.

9. Maxmudov S.Yu. Umaralieva M.A.The konsetual direction of prevention information threats in academic and educational publications // Journal of Foreign Language Teaching and Applied linguistics. J-FLTAL. 2016. Volume №2 (3). IBU Publication/ International Burch University. Bosnia-Hercegovina, Sarajevo. P 125-130.

10. Maxmudov S.Yu. Abdullaeva N.Sh. Variability of the educational system as a subject of scientific research // European research: Innovation in science, education and technology. XL International scientific and practical conference Journal. United Kingdom, London. 2018. P 89-91.

11. Maxmudov S.Yu. Improving the process of professional development of public educators on the basis of innovativevariable approach: Monograph // S.Yu.Mahmudov. $-\mathrm{T}$ : “IPAK YO'LI POLIGRAF” LLC printing house. -2021. B. 332.. 